\title{
Genetic and biochemical characterization of the two glutamine synthetases GSI and GSII of the phosphinothricyl-alanyl-alanine producer, Streptomyces viridochromogenes Tü494
}

\author{
Doris Hillemann, Tanja Dammann, Andreas Hillemann and Wolfgang Wohlleben* \\ Universität Bielefeld, Lehrstuhl für Genetik, D-33501 Bielefeld 1, Germany
}

(Received 2 April 1993; revised 23 April 1993; accepted 30 April 1993)

\begin{abstract}
The 1410 bp DNA region $(g \ln A)$ encoding glutamine synthetase I (GSI) from Streptomyces viridochromogenes was amplified by PCR, cloned and sequenced. The molecular mass of the deduced GSI protein (469 residues) was determined to be 50 kDa. The DNA region showed $90 \%$ nucleotide identity with the Streptomyces coelicolor A3(2) $g \ln A$ gene, but no significant nucleotide sequence similarity with the $g \ln I I$ (GSII) gene of $S$. viridochromogenes. The chromosomal $g \ln A$ and $g \ln I I$ genes of $S$. viridochromogenes were disrupted by site-specific mutagenesis. Neither $g \ln A$ nor $g \ln I I$ single mutants required glutamine for growth and both were normal in their sporulation. Measurement of the GS activity in cultures grown with different nitrogen sources revealed that GSI (heat-stable) and GSII (heat-labile) were always expressed together, with GSI as the predominant activity. It could be proposed that GSI, but not GSII is inactivated by adenylylation under conditions of nitrogen excess. GSI and GSII activities are inhibited by amino acids and by nucleotides.
\end{abstract}

\section{Introduction}

Glutamine synthetase (GS) (glutamate-ammonia ligase, EC 6.3.1.2) catalyses the conversion of $\mathrm{L}$-glutamic acid to L-glutamine in the presence of ammonia and ATP. Glutamine is a key metabolite in the synthesis of nitrogen-containing compounds such as purines, pyrimidines, amino sugars and various amino acids. Different forms of GS in one organism have been found in Rhizobiaceae (Darrow \& Knotts, 1977; Fuchs \& Keister, 1980), Frankia sp. (Edmands et al., 1987) and Streptomyces (Behrmann et al., 1990; Kumada et al., 1990), and a third type of GS was detected in the anaerobe Bacteroides fragilis (Hill et al., 1989).

There are three different types of GS. GSI are generally found in bacteria and are relatively heat-stable polymeric enzymes consisting of 12 identical subunits, each with 450 to 470 amino acids. GSII, composed of eight smaller

*Author for correspondence. Present address: Universität des Saarlandes, Abteilung Angewandte Molekularbiologie, D-66041 Saarbrücken, Germany. Tel. 681302 4730; fax 6813024710.

Abbreviations: GS, glutamine synthetase; $g \ln A$, gene encoding GSI; ginII, gene encoding GSII; MCS, multiple cloning site; PTT, phosphinothricyl-alanyl-alanine; SVPDE, snake venom phosphodiesterase.

The nucleotide sequence data reported in this paper have been submitted to EMBL and assigned the accession number X70924. subunits, each with 350 to 420 amino acids, are typical of eukaryotes but are also found in some bacteria, and are heat-labile. GSI, but not GSII, are known to be modified post-translationally by adenylylation (Darrow et al., 1981). GSI and GSII have about $15 \%$ amino acid identity concentrated in five conserved regions (Janssen et al., 1988; Rawlings et al., 1987). The GS of $B$. fragilis has six subunits, each with 729 amino acids, is not regulated by adenylylation and has no sequence similarity to the GSI and GSII enzymes (Hill et al., 1989).

Transcriptional and post-translational regulation of glnA have been extensively studied in the Enterobacteriaceae (for reviews see Reitzer \& Magasanik, 1987; Merrick, 1988).

Rhizobiaceae and actinomycetes contain both a GSI and a GSII activity. They are differently regulated in the well-studied Rhizobiaceae (Carlson \& Chelm, 1986). In Bradyrhizobium japonicum (Adams \& Chelm, 1988; Carlson \& Chelm, 1986) and Agrobacterium tumefaciens (Rossbach et al., 1987, 1988) the $g \ln A$-homologous gene appears to be expressed constitutively and GSI activity is controlled post-translationally (Darrow \& Knotts, 1977; Darrow et al., 1981; Ludwig 1978, 1980a,b). glnII expression is, however, regulated in response to the cellular nitrogen status by the Ntr system (Martin et al., 1988).

The metabolic regulation of nitrogen metabolism has been studied in different Streptomyces species. GS 
activity is dependent on the nitrogen source in $S$. cattleya, S. clavuligerus and S. coelicolor (Paress \& Streicher, 1985; Bascarán et al., 1989; Fisher \& Wray, 1989) but not in S. venezuelae (Shapiro \& Vining, 1983). Transcriptional control of the $g \ln A$ gene of $S$. coelicolor is mediated through an activator protein, $g \ln R$ (Wray et al., 1991) and GSI activity is regulated posttranslationally via adenylylation in $S$. cattleya, $S$. coelicolor, S. clavuligerus (Streicher \& Tyler, 1981; Fisher \& Wray, 1989; Bascarán et al., 1989). In recent studies, the existence of two GS genes in S. viridochromogenes and S. hygroscopicus was proved (Behrmann et al., 1990; Kumada et al., 1990). Much about the respective roles of the two gln genes and about their expression and regulation remains unclear (Fisher, 1992).

In $S$. viridochromogenes, examination of nitrogen assimilation metabolism is of particular interest, because this strain produces the antibiotic phosphinothricylalanyl-alanine (PTT), which contains the GS inhibitor phosphinothricin (Pt) (Bayer et al., 1972) and none of the GS enzymes are Pt-resistant, although overexpression of GSII gives PTT resistance (Behrmann et al., 1990). To analyse the expression and regulation of the two $g l n$ genes of $S$. viridochromogenes we constructed and analysed $g \ln A$ and $g \ln I I$ mutants by gene disruption techniques.

\section{Methods}

Strains. The wild-type strain Streptomyces viridochromogenes Tü494 (Bayer et al., 1972) was obtained from Professor H. Zähner, University of Tübingen, Germany. The GS mutants DH11 and DH22 were derived from this strain. Escherichia coli JM83 (Vieira \& Messing, 1982) was used in cloning experiments. Single-stranded DNA was isolated from $E$. coli NM522 (Gough \& Murray, 1983), after infection with helper phage M13KO7 (Martin, 1987). E. coli S17-1 (Simon et al., 1983), which carries the RP4 transfer functions chromosomally integrated, was used as donor in mating experiments between $E$. coli and $S$. viridochromogenes. Heterologous expression of $S$. viridochromogenes $g \ln A$ and $g \ln I I$ genes was investigated in $E$. coli strain YMC11 (Backman et al., 1981), which is a $g \ln A$ deletion mutant.

Culture conditions and genetic manipulations. For protoplasting, $S$. viridochromogenes mycelium was grown in S medium containing $0.75 \%$ glycine (Strauch et al., 1987). Transformation of S. viridochromogenes was carried out according to the protocol of Hopwood et al. (1985). Protoplasts were spread on R5 agar (Hopwood et al., 1985) and selection of thiostrepton-resistant colonies was carried out by overlaying the plates with thiostrepton after $18 \mathrm{~h}$ incubation. Thiostrepton was kindly provided by Dr S. J. Lucania (E. J. Squibb \& Sons, New York, USA).

Mating experiments with $E$. coli as donor and S. viridochromogenes spores as recipient were performed as described by Wohlleben \& Pielsticker (1989). Transformation of $E$. coli strains was performed as described by Cohen et al. (1972).

$S$. viridochromogenes was cultivated on $\mathrm{MYG}$ agar containing $\left(1^{-1}\right)$ : $10 \mathrm{~g}$ malt extract, $4 \mathrm{~g}$ yeast, $4 \mathrm{~g}$ glucose and $15 \mathrm{~g}$ agar, $\mathrm{pH} 7 \cdot 3$. Cultivation of $S$. viridochromogenes for enzyme assays was carried out in chemically defined medium containing $1 \mathrm{~g} \mathrm{~K}_{2} \mathrm{HPO}_{4}, 0.2 \mathrm{~g}$ $\mathrm{MgSO}_{4} .7 \mathrm{H}_{2} \mathrm{O}, 0.01 \mathrm{~g} \mathrm{FeSO}_{4} .7 \mathrm{H}_{2} \mathrm{O}, 10 \mathrm{~g}$ glucose in $50 \mathrm{mM}$-HEPES buffer $\mathrm{pH} 7 \cdot 6$. The medium was supplemented with different nitrogen sources at $20 \mathrm{~mm}$ concentration, as indicated.

Preparation, manipulation and sequencing of DNA. Total Streptomyces DNA was isolated by the method of Hopwood et al. (1985). E. coli plasmid DNA was isolated by the method of Holmes \& Quigley (1981), isolation of single-stranded phage DNA as described by Hillemann et al. (1991).

Manipulations in $E$. coli were performed using standard procedures (Maniatis et al., 1982). Restriction enzymes, T4 DNA ligase, alkaline phosphatase, DNA polymerase I and Taq polymerase were obtained from Gibco BRL or Boehringer Mannheim and used according to the suppliers' recommendations. Radioactive deoxynucleotides were purchased from Amersham or DuPont. DNA was sequenced following the protocol of Sanger et al. (1977). Both strands were sequenced. Fragments of interest were cloned into the sequencing vector pSVB30 (see Table 1).

Oligodeoxynucleotide synthesis. The chemicals required for the synthesis of DNA were purchased from Applied Biosystems. The oligonucleotides were synthesized with an Applied Biosystems DNA Synthesizer, Model 380B, using the phosphoramidite method (Beaucage \& Caruthers, 1981).

PCR. PCR (Mullis et al., 1986) was set up at $4{ }^{\circ} \mathrm{C}$. The $50 \mu$ reaction mixture consisted of $200 \mathrm{nM}$ of each oligonucleotide primer, $200 \mu \mathrm{M}$ d(NTP), 2.5 units Taq polymerase, $1 \mu \mathrm{g}$ linearized template DNA in PCR buffer (67 mM-DTT, $0.17 \mathrm{mg} \mathrm{BSA} \mathrm{ml}^{-1}$ ). The reaction mixture was overlaid with mineral oil. After the first denaturation, which lasted for $2.5 \mathrm{~min}$ at $94^{\circ} \mathrm{C}, 31$ cycles of amplification (at $94^{\circ} \mathrm{C}$ for $90 \mathrm{~s}, 57^{\circ} \mathrm{C}$ for $90 \mathrm{~s}$, and $72^{\circ} \mathrm{C}$ for $90-150 \mathrm{~s}$ dependent on the expected length of the template) were performed in a thermocycler (Collasius et al., 1989). PCR products were electrophoretically separated in a $0.8 \%$ agarose gel, isolated by the glass wool method (Mukhopadhyay \& Roth, 1991) and directly employed for cloning.

For the inverse PCR reaction (Ochman et al., 1990), the template DNA was pretreated by digestion with $S a l$ and religated at low DNA concentration to promote circularization (Collins \& Weissman, 1984). The primer pair 2 and 4 (Fig. 1) was used for the PCR reaction. Primers for PCR are homologous to the end of the core region, but oriented such that chain elongation proceeds across the unknown region of the circle.

The following oligonucleotide primers were used: $5^{\prime}$ ATG TTC CAG AAC GCC GAC $3^{\prime}$ (primer 1), 5' GAC GGC ATC AAG AAC AAG ATC $3^{\prime}$ (primer 2), 3' CTG CCG TAG TTC TTG TTC TAG 5' (primer 3), 3' TAC ATG AAG CTG CAC ACT 5' (primer 4).

Determination of PTT resistance and PTT production. Measurement of the PTT resistance level was performed on minimal agar containing $\left(\mathrm{NH}_{4}\right)_{2} \mathrm{SO}_{4}(20 \mathrm{~mm})$ as nitrogen source (Hopwood et al., 1985) supplemented with different PTT concentrations. PTT was kindly supplied by Hoechst. The bioassay for determining PTT production was done as described by Alijah et al. (1991).

GS assays. GS assays were performed in crude extracts. Before preparation of crude extracts the cells were washed twice with buffer (50 mM-imidazole, pH 7.0, $150 \mathrm{~mm}-\mathrm{NaCl}, 1 \mathrm{~mm}-\mathrm{MnCl}_{2}, 0.5 \mathrm{~mm}-\mathrm{DTT}$ ). The cells were resuspended in the same buffer and disrupted in a French press at $1.07 \times 10^{8} \mathrm{~Pa}$. GS was assayed by the $\gamma$-glutamyltransferase method (Bender et al., 1977), modified as described previously (Behrmann et al., 1990). The procedure measures the ability of GS to replace the $\gamma$-amino group of glutamine with hydroxylamine in the presence of $\mathrm{ADP}$ and $\mathrm{AsO}_{4}^{3-}$. Reactions were started by adding glutamine. Since GSI and GSII have approximately the same $\mathrm{pH}$ optima in the transferase assay reaction (data not shown), mixtures containing $50 \mathrm{mM}$-imidazole buffer ( $\mathrm{pH} \mathrm{7.0)}$ ) were used. The activity of the heat-stable GSI was determined after heat treatment of the crude 
Table 1. Plasmids

\begin{tabular}{|c|c|c|}
\hline Plasmid & Relevant characteristics and marker gene(s)* & Source or reference \\
\hline pSVB30 & $\begin{array}{l}\text { Sequencing vector derived from pUC8 (Vieira \& Messing, 1982); } \\
\text { mcs bla lac } Z^{\prime}\end{array}$ & Arnold \& Pühler (1988) \\
\hline pUC18/19† & Cloning vector; bla lac $Z^{\prime}$ & Norrander et al. (1983) \\
\hline pK $18:: m o b$ & Mobilization vector derived from pK18 (Pridmore, 1987); aphII & Sonnen et al. (1991) \\
\hline pDH5 & $\begin{array}{l}\text { Multifunctional vector derived from pUC19 with } \mathrm{T}_{7} \text { and } \mathrm{T}_{3} \\
\text { promoters and phage f1 intergenic region for the isolation of single- } \\
\text { stranded DNA; mcs bla lac } Z^{\prime} \text { tsr }\end{array}$ & Hillemann et al. (1991) \\
\hline pDH18.1 & $\begin{array}{l}\text { pUC18 containing the } g \ln A \text { gene of } S . \text { viridochromogenes expressed } \\
\text { from the lac } Z \text { promoter; bla }\end{array}$ & This study \\
\hline pDH19.2 & $\begin{array}{l}\text { pUC19 containing the } g l n I I \text { gene of } S \text {. viridochromogenes expressed } \\
\text { from the lacZ promoter; bla }\end{array}$ & This study \\
\hline pDH22 & $\begin{array}{l}\text { pDH5 carrying an internal fragment of the glnII coding region of } S \text {. } \\
\text { viridochromogenes; bla tsr (Fig. 3) }\end{array}$ & This study \\
\hline pDH11 & $\begin{array}{l}\text { pK } 18:: \text { mob carrying a } 1.2 \mathrm{~kb} \text { internal } g \ln A \text { fragment (PCR-generated } \\
\text { fragment with the primers } 1 \text { and } 3 \text { ) disrupted by the } 1.05 \mathrm{~kb} B c l \mathrm{I} \\
\text { tsr cassette; aphII tsr (Fig. 3) }\end{array}$ & This study \\
\hline
\end{tabular}

* Genes: aphII aminoglycoside phosphotransferase gene from Tn5 (selection in E. coli and Streptomyces); bla, $\beta$-lactamase gene from $E$. coli (selection in $E$. coli); lac $Z^{\prime}$, truncated $\beta$-galactosidase (lacZ) gene; tsr, thiostrepton resistance gene from $S$. azureus (selection in Streptomyces).

$\dagger$ This pair of plasmids differ in the orientation of their mcs.

extracts at $60^{\circ} \mathrm{C}$ for $10 \mathrm{~min}$ prior to the enzyme essay (Edmands et al., 1987). The contributions of GSI and GSII in the wild-type were determined by comparing $\gamma$-glutamyltransferase activity of crude extracts before and after heat treatment. Protein concentration was determined by the dye-binding protein assay (Bio-Rad).

Modification of GS from exponentionally grown cells was performed as described by Braña et al. (1986), but examined in crude extracts and not in whole cells. Reactivation of GS in crude extracts was tested in $20 \mathrm{~mm}$-imidazole $/ \mathrm{HCl} \mathrm{pH} 7 \cdot 0$, containing $2.5 \mathrm{~mm}-\mathrm{MnCl}_{2}$. The extracts were incubated at $37^{\circ} \mathrm{C}$ with snake venom phosphodiesterase (SVPDE, Boehringer Mannheim) at $100 \mu \mathrm{g} \mathrm{ml}^{-1}$.

Construction of plasmids $p D H 18.1$ and pDH19.2. The plasmid $\mathrm{pDH} 19.2$ carries the $g \ln I I$ gene of $S$. viridochromogenes expressed under the control of the $E$. coli lac $Z$ promoter in the plasmid pUC19. Partially Sau 3 AI digested fragments in the $2-4 \mathrm{~kb}$ range were isolated from $S$. viridochromogenes total DNA and ligated into the BamHI site of the vector pUC19. The ligation mixture was used for the transformation of the $E$. coli ginA mutant YMC11 (Backman et al,, 1981). Two transformants that grew on minimal medium were selected. Further analysis of these transformants showed that they harboured plasmids carrying an identical $1.5 \mathrm{~kb}$ insert. Restriction analysis revealed that the cloned fragments of these plasmids represent the $g \ln I I$ gene of $S$. viridochromogenes (Behrmann et al., 1990).

To construct the plasmid pDH18.1 which carries the $g \ln A$ gene of $S$. viridochromogenes expressed under the control of the $E$. coli lac $Z$ promoter of the plasmid pUC18, three fragments of $g \ln A$ DNA were cloned in $5^{\prime}-3^{\prime}$ direction into the SmaI/SalI-digested $E$. coli vector pUC18: (1) a $0.6 \mathrm{~kb}$ blunt-ended/PstI fragment generated by PstIdigestion of the $0.8 \mathrm{~kb}$ PCR product (primer pair 1 and 4); (2) a $0.7 \mathrm{~kb}$ PstI fragment isolated from the $S$. viridochromogenes chromosomal DNA; and (3) a $0.1 \mathrm{~kb} P s t \mathrm{I} /$ Sall fragment in the $3^{\prime}$ region of the $g \ln A$ gene generated by the inverse PCR with the primer pair 4 and 2 (Fig. 1).

Construction of plasmids pDH11 and pDH22. pDH11 (Fig. 3) consists of the $1.2 \mathrm{~kb} g \ln A$ fragment PCR-generated with the primers 1 and 3 (Fig. 1) cloned into the $S m a I$ site of the mobilizable $E$. coli vector pK $18:: m o b$ and the $1.05 \mathrm{~kb} B c / \mathrm{I} t s r$ cassette (thiostrepton resistance) inserted into the unique $B g I I$-site of the $g \ln A$ fragment. pDH22 (Fig. 3) consists of pDH5, carrying an internal $300 \mathrm{bp} \mathrm{BgIII/Sau3AI}$ fragment of the glnII coding region of S. viridochromogenes inserted into the single BamHI site of the mcs.

\section{Results and Discussion}

Cloning and sequence analysis of the $S$. viridochromogenes glnA coding region

To isolate the $g \ln A$ coding region of $S$. viridochromogenes, the PCR method was applied for amplifying and cloning internal segments of the $\operatorname{gln} A$ gene (Fig. 1). Oligonucleotide primers 1-4 (see Methods and Fig. 1) were designed according to the known $S$. coelicolor $g \ln A$
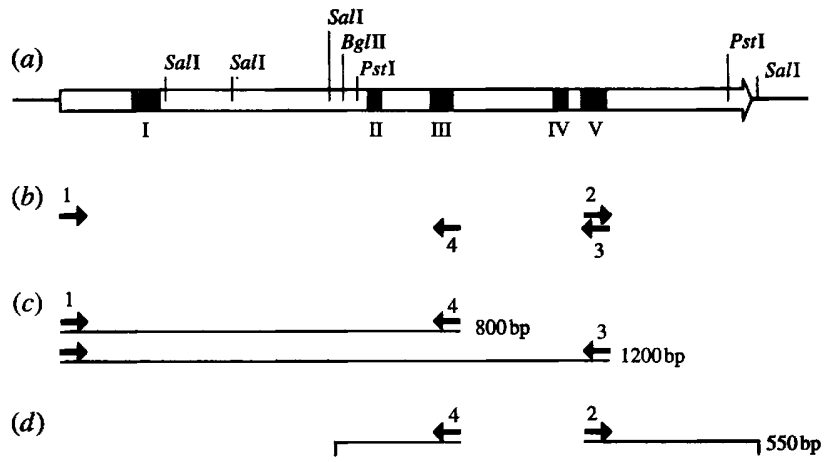

Fig. 1. Physical map, oligonucleotide primers and amplified PCR fragments of the $S$. viridochromogenes $g \ln A$ coding region. A restriction map of the $1.4 \mathrm{~kb} g \ln A$ coding region from $S$. viridochromogenes is shown above the physical map $(a)$. Shaded areas within the $S$. viridochromogenes $g \ln A$ coding region indicate the conserved regions I-V which are common in GSI and GSII protein sequences. Arrows beneath the physical map mark the location of the oligonucleotide primers used for PCR $(b)$. The bars at the bottom represent the 800 and 1200 bp PCR-amplified fragments $(c)$ and the 550 bp Sall fragment generated by inverse PCR $(d)$. 


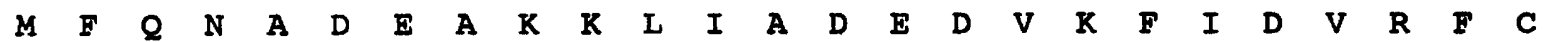
ATGTTCCAGAACGCCGACGAGGCCAAGAAGTTGATCGCGGACGAGGACGTCAAGTTCATCGACGTCCGCTTCTGC 75

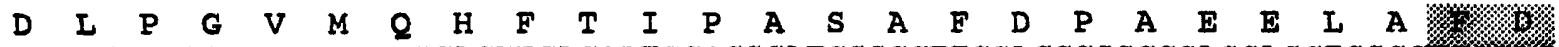
GACCTGCCGGGCGTGATGCAGCACTTCACGATCCCCGCATCGGCCTTCGACCCGGCCGAGGAGCTGGCC

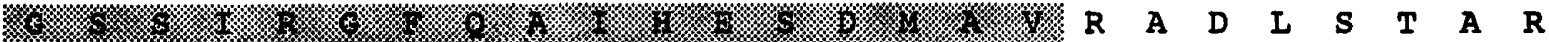
F. $\operatorname{SaII}$

$\begin{array}{lllllllllllllllllllllllll}\mathbf{V} & \mathbf{D} & \mathbf{P} & \mathbf{F} & \mathbf{R} & \mathbf{R} & \mathbf{D} & \mathbf{K} & \mathbf{T} & \mathbf{V} & \mathbf{N} & \mathbf{I} & \mathbf{N} & \mathbf{F} & \mathbf{F} & \mathbf{I} & \mathbf{H} & \mathbf{D} & \mathbf{P} & \mathbf{I} & \mathbf{T} & \mathbf{G} & \mathbf{E} & \mathbf{Q} & \mathbf{Y}\end{array}$ GTCGACCCGTTCCGCGTGACAAGACGGTCAACATCAACTTCTTCATCCACGACCCGATCACGGGCGAGCAGTAC 300

$\begin{array}{llllllllllllllllllllllllll}\mathbf{S} & \mathbf{R} & \mathbf{D} & \mathbf{P} & \mathbf{R} & \mathbf{N} & \mathbf{V} & \mathbf{A} & \mathbf{K} & \mathbf{K} & \mathbf{A} & \mathbf{E} & \mathbf{A} & \mathbf{Y} & \mathbf{L} & \mathbf{A} & \mathbf{S} & \mathbf{T} & \mathbf{G} & \mathbf{I} & \mathbf{G} & \mathbf{D} & \mathbf{T} & \mathbf{G} & \mathbf{Y}\end{array}$ TCCCGTGACCCGCGCAACGTGGCGAAGAAGGCCGAGGCCTACCTCGCGTCGACCGGTATCGGGGACACCGGCTAC 375 SalI

$\begin{array}{llllllllllllllllllllllllll}\mathbf{F} & \mathbf{G} & \mathbf{P} & \mathbf{E} & \mathbf{A} & \mathbf{E} & \mathbf{F} & \mathbf{Y} & \mathbf{V} & \mathbf{F} & \mathbf{D} & \mathbf{S} & \mathbf{V} & \mathbf{R} & \boldsymbol{L} & \mathbf{A} & \mathbf{N} & \mathbf{S} & \mathbf{A} & \mathbf{T} & \mathbf{E} & \mathbf{S} & \mathbf{F} & \mathbf{Y} & \mathbf{H}\end{array}$ TTCGGCCCCGAGGCCGAGTTCTACGTCTTCGACTCCGTGCGCTTGGCGAACAGCGCGACCGAGTCCTTCTACCAC 450

$\begin{array}{lllllllllllllllllllllllll}I & D & S & \mathbf{E} & A & \mathbf{G} & \mathbf{A} & \mathbf{W} & \mathbf{N} & \mathbf{T} & \mathbf{G} & \mathbf{A} & \mathbf{L} & \mathbf{E} & \mathbf{N} & \mathbf{N} & \mathbf{R} & \mathbf{G} & \mathbf{Y} & \mathbf{K} & \mathbf{V} & \mathbf{R} & \mathbf{Y} & \mathbf{K} & \mathbf{G}\end{array}$ ATCGACTCCGAGGCCGGCGCCTGGAACACCGGTGCCCTCGAGAACAACCGTGGTTACAAGGTCCGCTACAAGGGC 525

$\begin{array}{llllllllllllllllllllllllll}\mathbf{G} & \mathbf{Y} & \mathbf{F} & \mathbf{P} & \mathbf{V} & \mathbf{P} & \mathbf{P} & \mathbf{V} & \mathbf{D} & \mathbf{H} & \mathbf{F} & \mathbf{A} & \mathbf{D} & \mathbf{L} & \mathbf{R} & \mathbf{A} & \mathbf{Q} & \mathbf{I} & \mathbf{S} & \mathbf{L} & \mathbf{E} & \mathbf{L} & \mathbf{D} & \mathbf{R} & \mathbf{A}\end{array}$ GGCTACTTCCCGGTCCCGCCGGTCGACCACTTCGCCGACCTGCGTGCCCAGATCTCCCTGGAGCTGGACCGTGCC 6OO SaII BgIII

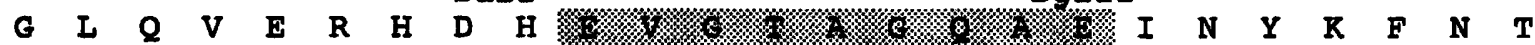
GGTCTGCAGGTGGAGCGCCACGACCAC PstII II

$\begin{array}{llllllllllllllllllllllllll}I & I & A & A & A & D & D & I & \mathbf{Q} & I & \mathbf{F} & \mathbf{K} & \mathbf{Y} & \mathbf{I} & \mathbf{V} & \mathrm{K} & \mathbf{N} & \mathbf{V} & \mathbf{A} & \mathbf{W} & \mathbf{Q} & \mathbf{N} & \mathbf{G} & \mathbf{R} & \mathbf{T}\end{array}$ CTGCTCGCCGCGGCCGACGACCTCCAGCTCTTCAAGTACATCGTGAAGAACGTGGCGTGGCAGAACGGCAAGACC 750

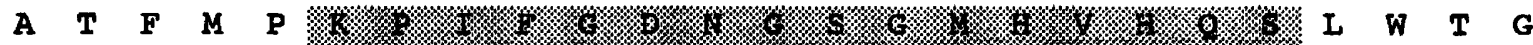
GCGACCTTCATGCCG\% \% 11

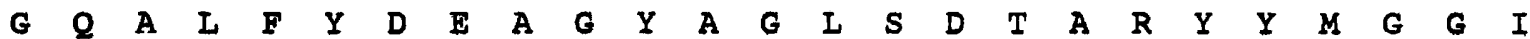
GGCCAGGCGCTCTTCTACGACGAGGCCGGTTACGCGGGCCTGTCGGACACCGCCCGCTACTACATGGGCGGCATC 900

$\begin{array}{lllllllllllllllllllllllll}\mathbf{L} & \mathbf{K} & \mathbf{H} & \mathbf{A} & \mathbf{P} & \mathbf{S} & \mathbf{I} & \mathbf{L} & \mathbf{A} & \mathbf{F} & \mathbf{T} & \mathbf{N} & \mathbf{P} & \mathbf{T} & \mathbf{V} & \mathbf{N} & \mathbf{S} & \mathbf{Y} & \mathbf{H} & \mathbf{R} & \mathbf{L} & \mathbf{V} & \mathbf{P} & \mathbf{G} & \mathbf{F}\end{array}$ CTCAAGCACGCCCCGTCGCTGCTGGCCTTCACCAACCCGACGGTGAACTCGTACCACCGCCTGGTGCCGGGCTTC 975

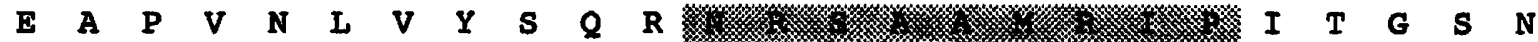
GAGGCGCCGGTCAACCTGGTCTACTCGCAGCGC, 17

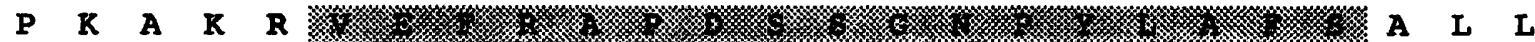

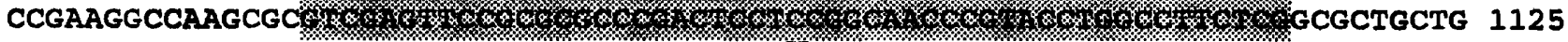
$\checkmark$

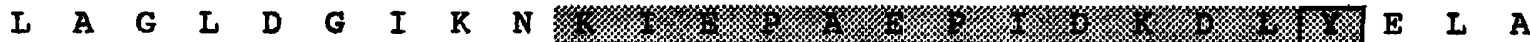

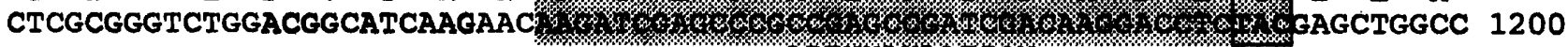
ADENYLYLATION

$\begin{array}{llllllllllllllllllllllllll}\mathbf{P} & \mathbf{E} & \mathbf{E} & \mathbf{H} & \mathbf{A} & \mathbf{G} & \mathbf{V} & \mathbf{P} & \mathbf{Q} & \mathbf{V} & \mathbf{P} & \mathbf{T} & \mathbf{S} & \mathbf{L} & \mathbf{P} & \mathbf{A} & \mathbf{V} & \mathbf{L} & \mathbf{D} & \mathbf{R} & \mathbf{L} & \mathbf{E} & \mathbf{A} & \mathbf{D} & \mathbf{H}\end{array}$ CCCGAGGAGCACGCGGGCGTCCCGCAGGTCCCGACCTCGCTCCCGGCCGTCCTCGACCGTCTGGAGGCCGACCAC 1275

$\begin{array}{lllllllllllllllllllllllll}\mathbf{E} & \mathbf{F} & \mathbf{L} & \mathbf{I} & \mathbf{A} & \mathbf{G} & \mathbf{D} & \mathbf{V} & \mathbf{F} & \mathbf{T} & \mathbf{P} & \mathbf{D} & \mathbf{L} & \mathbf{I} & \mathbf{E} & \mathbf{T} & \mathbf{W} & \mathbf{I} & \mathbf{D} & \mathbf{Y} & \mathbf{K} & \mathbf{R} & \mathbf{T} & \mathbf{N} & \mathbf{E}\end{array}$ GAGTTCCTGCTCGCGGGCGAGTCTTCACGCCGGACCTGATCGAGACGTGGATCGACTACAAGCGCACGAACGAG 1350

$\begin{array}{lllllllllllllllllll}I & \mathbf{A} & \mathbf{P} & \mathbf{L} & \mathbf{Q} & \mathbf{L} & \mathbf{R} & \mathbf{P} & \mathbf{H} & \mathbf{P} & \mathbf{Y} & \mathbf{E} & \mathbf{Y} & \mathbf{E} & \mathbf{Q} & \mathbf{Y} & \mathbf{Y} & \mathbf{D} & \mathbf{V}\end{array}$ ATCGCCCCGCTGCAGCTCCGCCCGCACCCGTACGAGTACGAGCÄGTACTACGACGTGTGA 1410 PstI

Fig. 2. Nucleotide sequence and deduced amino acid sequence of the $\operatorname{gin} A$ coding region from $S$. viridochromogenes. Restriction sites shown in Fig. 1 are underlined. The five regions (I-V) of high amino acid homology between GS enzymes and the putative adenylylation region are highlighted by stippling. The tyrosyl residue which may be subject to adenylylation is boxed. 
Table 2. GS activity of different E. coli and S. viridochromogenes strains

\begin{tabular}{|c|c|c|c|}
\hline \multirow[b]{2}{*}{ Strain* } & \multicolumn{2}{|c|}{$\begin{array}{c}\text { GS activity } \dagger \\
{\left[\mathrm{nmol} \gamma-\mathrm{GH} \min ^{-1}(\text { mg protein })^{-1}\right]}\end{array}$} & \multirow{2}{*}{$\begin{array}{l}\text { Reduction of GS } \\
\text { activity after } \\
\text { heat treatment (\%) }\end{array}$} \\
\hline & $\begin{array}{l}\text { Without heat } \\
\text { treatment }\end{array}$ & $\begin{array}{l}\text { With heat treatment } \\
\left(10 \mathrm{~min}, 60^{\circ} \mathrm{C}\right)\end{array}$ & \\
\hline \multicolumn{4}{|l|}{ E. coli } \\
\hline YMC11 (pUC19) & 0 & 0 & - \\
\hline YMC11 (pDH18.1) $(\ln \ln A)$ & 1381 & 1340 & 3 \\
\hline YMC11 (pDH19.2) (gInIn) & 1220 & 15 & 99 \\
\hline \multicolumn{4}{|l|}{ S. viridochromogenes } \\
\hline Wild-type & 943 & 778 & 17.5 \\
\hline DH22 (glnII mutant) & 838 & 822 & 2 \\
\hline DH11 (gln $A$ mutant) & 249 & 6 & 97.5 \\
\hline
\end{tabular}

* $S$. viridochromogenes and its mutants were grown in minimal medium supplemented with $20 \mathrm{~mm}$-asparagine as nitrogen source as indicated in Methods. $E$. coli cells were grown in penassay medium (antibiotic medium III; Oxoid).

$\dagger$ GS activity was measured by the $\gamma$-glutamyltransferase assay. The GS activity values are means of five assays, SEM was not more than $7 \%$.

DNA sequence (Wray \& Fisher, 1988). Primer 1 corresponds precisely to the $5^{\prime}$ end of the $S$. coelicolor $\operatorname{gln} A$ coding sequence. Primers 1 and 4 produced a $800 \mathrm{bp}$ DNA fragment, primers 1 and 3 a $1200 \mathrm{bp}$ fragment. Furthermore inverse PCR (Ochman et al., 1990) with primers 4 and 2 produced a $550 \mathrm{bp} \mathrm{SalI}$ fragment, which included the putative $3^{\prime}$ terminus of the $\operatorname{gln} A$ coding region.

The amplified fragments of 800,1200 and $550 \mathrm{bp}$ (Fig. 1) were cloned by blunt-end ligation into the unique SmaI-site of the sequencing vector pSVB30. This, together with an internal 700 bp PstI fragment (Fig. 1) cloned from the $S$. viridochromogenes chromosomal DNA represented the complete coding region of the $S$. viridochromogenes $g \ln A$ gene except for the $18 \mathrm{bp}$ oligonucleotide primer of the $5^{\prime}$ region. The $1410 \mathrm{bp}$ DNA sequence (the entire coding region) of the $\operatorname{gln} A$ gene and the deduced sequence of the 469 amino acid GSI enzyme are shown in Fig. 2. The sequences of the $700 \mathrm{bp}$ chromosomal PstI fragment and the DNA sequence derived from the PCR-amplified fragments were identical, indicating that the PCR amplifications, at least in this region, worked with high fidelity.

The coding region has a $\mathrm{G}+\mathrm{C}$ content of $67 \%$, and a codon usage typical for Streptomyces genes with 63, 40 and $97 \% \mathrm{G}+\mathrm{C}$ in the first, second and third codon position (Wright \& Bibb, 1992).

The amino acid sequence of the putative $S$. viridochromogenes GSI protein showed $91 \%$ identity with the putative $S$. coelicolor A3(2) GSI protein sequence. Interestingly, $S$. viridochromogenes (and $S$. coelicolor) GSI seemed more closely related to those of Gramnegative bacteria such as E. coli, Azospirillum brasilense and Azotobacter vinelandii (51, 54 and $53 \%$ identity, respectively) than to those of Gram-positive bacteria like Bacillus species or Clostridium acetobutylicum (40-44\% identity). Only $14 \%$ identity was found with the $S$. viridochromogenes GSII protein sequence.

To our knowledge, this is the first example where two GS genes from the same organism have been sequenced. Kumada et al. (1993) propose that the two genes are products of a gene duplication which occurred very early in the evolution of life, before the emergence of eukaryotes.

All five regions which are conserved in GSI and GSII proteins (Janssen et al., 1988; Rawlings et al., 1987) are also present in the putative GSI protein of $S$. viridochromogenes (stippled regions in Fig. 2). Regions I, II and V were proposed to form the active site which is formed between adjacent subunits (Almassy et al., 1986). Region III may be involved in nucleotide binding (Tischer et al., 1986). Amino acids 385-397 match perfectly the consensus sequence of the GSI adenylylation motif in the PROSITE Dictionary [A. Bairoch, University of Geneva; accessed by programme MOTIFs of the UWGCG sequence analysis package (Devereux et al., 1984)]. The tyrosyl residue 398 of $g \ln A$ of Salmonella typhimurium is adenylylated under conditions of abundant glutamine (Heinrikson \& Kingdon, 1971), but some GS contain a tyrosyl residue in the corresponding region without being adenylylated (Tronick et al., 1973; Fisher et al., 1981). Therefore, the function of the tyrosyl residue 397 of the $S$. viridochromogenes GS needs to be tested experimentally.

The adenylylation motif and, of course, the high similarity to the $S$. coelicolor A3(2) GSI enzyme support the claim that the cloned DNA sequence encodes a GSItype enzyme. 
Different heat stability of S. viridochromogenes GSI and GSII expressed in E. coli

It is known that GSI and GSII activities can be distinguished by their thermostabilities (Darrow \& Knotts, 1977). The $S$. viridochromogenes GS were tested for heat-stable and heat-labile GS transferase activities after expression in E. coli. The $S$. viridochromogenes $g \ln A$ and $g \ln I I$ genes were cloned into the $E$. coli vectors pUC18 and pUC19 to give pDH18.1 and pDH19.2, respectively, and introduced by transformation into the $E$. coli $g \ln A$ mutant YMC11. Both plasmids complemented the glutamine auxotrophy of strain YMC11. Heat-stable GSI activity was detected in crude extracts of YMC11 (pDH18.1), and heat-labile GSII activity in YMC11 (pDH19.2) (Table 2). These experiments also proved that the cloned $g \ln A$ and $g \ln I I$ genes of $S$. viridochromogenes were functional and that the $g \ln I I$ (GSII) gene of $S$. viridochromogenes is able to replace the natural $g \ln A$ (GSI) gene of $E$. coli.

\section{Construction of a glnA mutant of S. viridochromogenes by gene disruption}

To disrupt the $g \ln A$ gene of $S$. viridochromogenes, $\mathrm{pDH} 11$ (Fig. 3) carrying an internal DNA fragment from the $\operatorname{gln} A$ gene was constructed. $\mathrm{pDH} 11$ was introduced by transformation into $E$. coli $\mathrm{S} 17-1$ and delivered by conjugation to $S$. viridochromogenes. $\mathrm{pDH} 11$ DNA $(100 \mu \mathrm{g})$ isolated from $E$. coli JM83 was introduced by PEG-mediated transformation into $S$. viridochromogenes protoplasts. Conjugation and transformation gave each a single thiostrepton- and kanamycin-resistant colony, which presumably contained $\mathrm{pDH} 11$ integrated into the chromosomal $g \ln A$ gene. This was confirmed for both clones by Southern hybridization experiments using the $1.2 \mathrm{~kb}$ PCR fragment (Fig. 1) cloned into pUC19 as probe. Both strains showed the same hybridization pattern (not shown), indicating that pDH11 had integrated via a single crossover in the $5^{\prime}$ region of the $g \ln A$ gene. One descendant, $S$. viridochromogenes DH11, derived from the conjugation experiment, was propagated on MYG agar without antibiotics twice, 500 colonies were tested and all of them had retained the thiostrepton and kanamycin resistance markers, indicating stable integration of the entire pDH11 (no second crossover event occurred).

\section{Construction of a glnII mutant of S. viridochromogenes by gene disruption}

For the generation of a glnII mutant, plasmid pDH22 (Fig. 3) was constructed. An internal $300 \mathrm{bp}$ $B g I I I / S a u 3 A I$ fragment of the $g \ln I I$ coding region
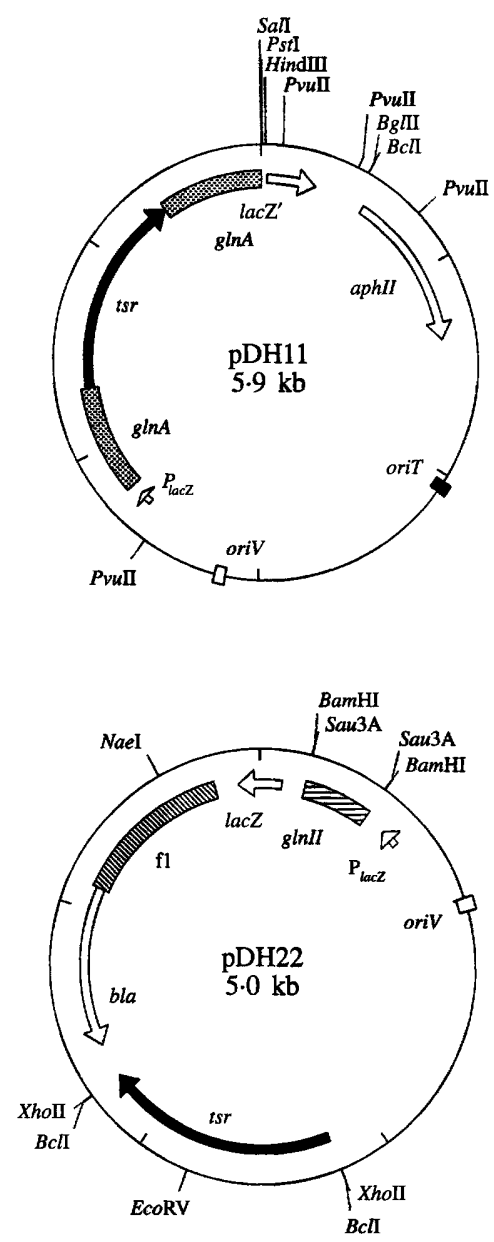

Fig. 3. Restriction maps of the plasmids used for the disruption of the $\operatorname{gln} A$ and the $g \ln I$ genes of $S$. viridochromogenes. pDH11 was derived from the $E$. coli vector $\mathrm{pK} 18:: m o b$ with the origin of transfer (oriT) of plasmid RP4. It carries a $1.2 \mathrm{~kb}$ internal $g \ln A$ fragment $(g \ln A)$, disrupted by the thiostrepton resistance cassette. pDH22 was derived from the $E$. coli vector pDH5 which carries the phage $\mathrm{f} 1$ intergenic region for the generation of single-stranded DNA. pDH22 contains a $300 \mathrm{bp}$ internal $g \ln I I$ gene fragment $(g \ln I I)$. pDH11 and pDH22 contain the pUC (ColE1) replication function (oriV). Only restriction sites relevant for construction and cloning are given. For gene designations and further descriptions, see Table 1.

(Behrmann et al., 1990) was cloned into the unique BamHI-site of the vector pDH5 (Table 1), which can be isolated in single- and double-stranded form. About 100 thiostrepton-resistant $S$. viridochromogenes transformants were obtained for $1 \mu \mathrm{g}$ single-stranded DNA. Southern analysis of six transformants confirmed that in each case one complete plasmid had integrated into the glnII gene by homologous recombination (not shown). One of these transformants, S. viridochromogenes $\mathrm{DH} 22$, with the integrated plasmid $\mathrm{pDH} 22$ was chosen for further studies. The stability of the integration was tested by determination of marker loss after two cycles of sporulation on MYG medium without antibiotics. No 
loss of thiostrepton resistance occurred in 200 colonies tested. This indicated stable integration of $\mathrm{pDH} 22$ into the chromosome of $S$. viridochromogenes DH22.

Heat-stable (GSI) and heat-labile (GSII) activities in S. viridochromogenes $\mathrm{DH} 11$ and $\mathrm{DH} 22$

Crude extracts were prepared from exponentionally growing wild-type $S$. viridochromogenes $\mathrm{DH} 11$ and DH22 cells, and GS transferase activities were determined before and after heat treatment (Table 2). The wild-type strain contained both a heat-stable $(82 \%)$ and a heat-labile (18\%) activity. In DH22 only heat-stable (GSI) activity could be found, confirming functional disruption of the $g \operatorname{lnII}$ gene. In DH11 all GS activity was heat-labile (GSII), confirming the functional disruption of the $g \ln A$ gene.

Growth, sporulation and PTT-production of the $S$. viridochromogenes gln mutant strains on different media

The two GS in $S$. viridochromogenes might be required for the assimilation (utilization) of different nitrogen sources. Therefore, wild-type and $g l n$ mutants were tested for growth on minimal plates supplemented with a variety of nitrogen sources (ammonia, nitrate, glutamine, glutamic acid, asparagine, aspartic acid, alanine, glycine, serine). Neither $S$. viridochromogenes DH11 nor DH22 required glutamine for growth, suggesting that sufficient glutamine could be provided by either GS alone.

Both strains grew at about the same rate as the wildtype strain on most nitrogen sources tested. A few minimal differences in growth behaviour could, however, be noticed. For example, on glutamic acid, the $\operatorname{gln} A$ mutant grew more slowly than the wild-type and the $g \ln I I$ mutant. Similar observations were made with $g l n$ mutants in rhizobia and agrobacteria, where GSI and GSII-deficient strains were glutamine prototrophs and grew on minimal medium supplemented with a variety of nitrogen sources (Rossbach et al., 1988; de Bruijn et al., 1989). Double mutants were, however, auxotrophic (Rossbach et al., 1988; de Bruijn et al., 1989).

Disruption of the $S$. viridochromogenes $g \ln I I$ or $g \ln A$ gene did not result in a general sporulation deficiency. On most nitrogen sources, $g \ln$ mutants could hardly be distinguished from the wild-type with respect to development of aerial mycelia or sporulation. It is interesting to note that aerial mycelium of $\mathrm{DH} 22$ developed earlier than that of the wild-type or DH11 strains if alanine was the sole nitrogen source. Sporulation of the $g \ln A$ mutant was delayed and diminished with the branched-chain amino acids isoleucine and leucine as sole nitrogen sources.

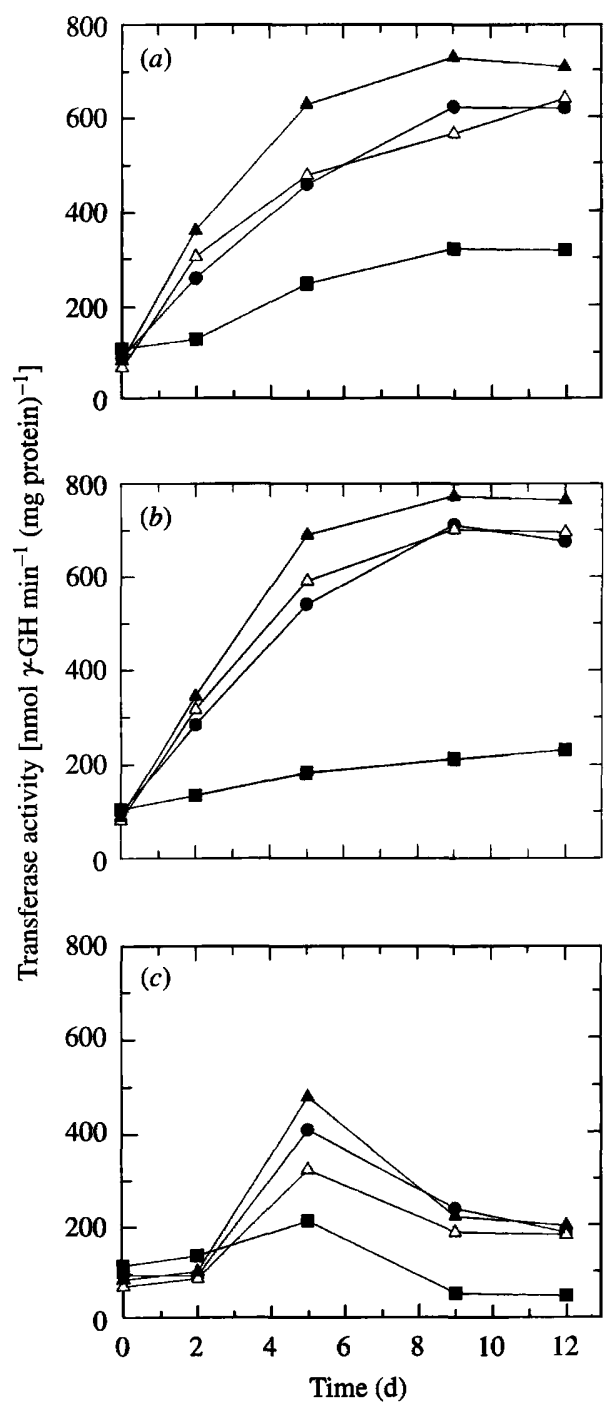

Fig. 4. GS activities in wild-type $S$. viridochromogenes and GS mutant strains. Cells growing exponentially in complex medium were transferred at time 0 to media containing asparagine (a), ammonia $(b)$ or no nitrogen source $(c)$. Every $2 \mathrm{~d}, 2 \mathrm{ml}$ samples were taken. GSI activity was measured in crude extracts of the glnII mutant (O), GSII activity in the $g \ln A$ mutant (D) and combined GSI/GSII activity in the wildtype $(\boldsymbol{\Delta})$. Heat-stable GS activity of the wild-type $(\triangle)$ was determined after heat treatment of crude extracts for $10 \mathrm{~min}$ at $60^{\circ} \mathrm{C}$. The specific activities are expressed as nmol $\gamma$-glutamyl hydroxamate $(\gamma-\mathrm{GH})$ formed $\mathrm{min}^{-1}$ (mg protein $)^{-1}$. SEM of three measurements was not more than $10 \%$.

Both DH11 and DH22 produced PTT but the amount depended on the nitrogen source. On some nitrogen sources, PTT production of the gln mutants and the wildtype was approximately the same (asparagine, valine, aspartic acid, proline, threonine, tyrosine, $\left(\mathrm{NH}_{4}\right)_{2} \mathrm{SO}_{4}$, $\mathrm{NH}_{4} \mathrm{Cl}$ ). PTT production of the $\operatorname{gin} I I$ mutant was reduced $66 \%$ on glutamic acid, $50 \%$ on glycine and $75 \%$ on arginine. The $g \ln A$ mutant produced less PTT on glycine and alanine (50\% reduction), isoleucine and leucine 
(a)

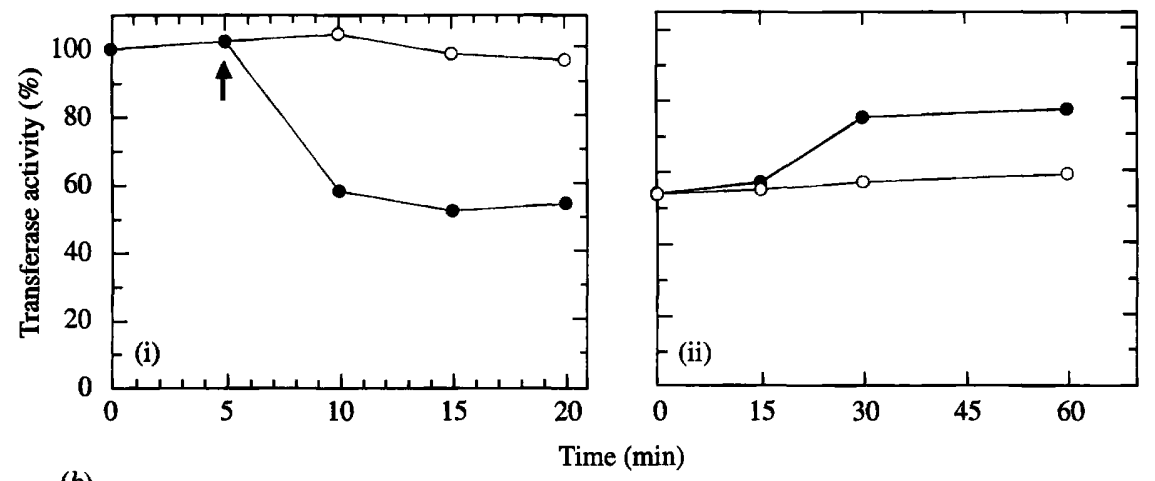

(b)

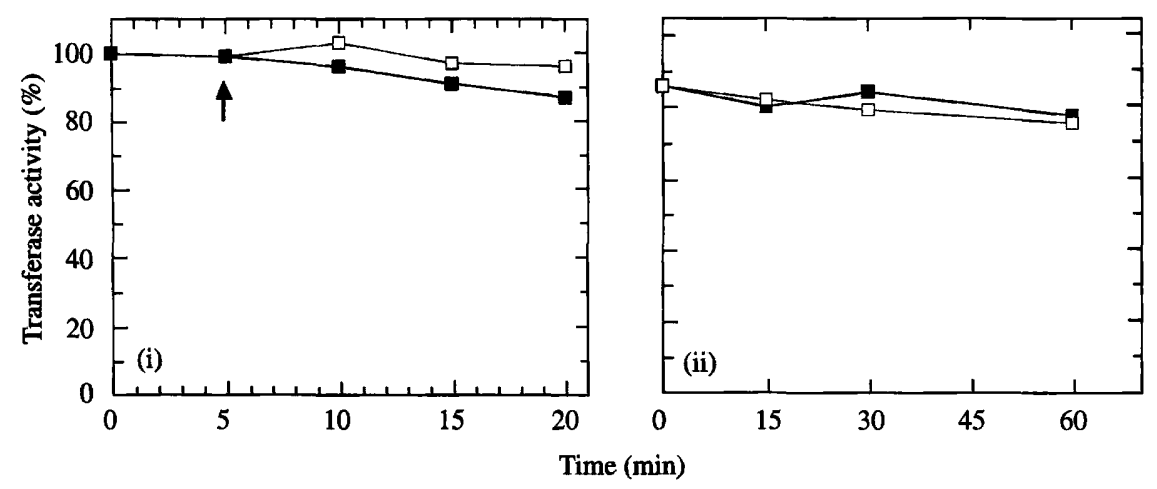

Fig. 5. Test for in vivo covalent modification of the GSI and GSII in S. viridochromogenes. $S$. viridochromogenes glnII mutant $(a, \mathrm{DH} 22)$ and gln $A$ mutant (b, DH11) cells were grown in $100 \mathrm{ml}$ minimal medium supplemented with asparagine and assayed for GS transferase activity by preparing crude extracts of $2 \mathrm{ml}$ samples at time 0 . At $5 \mathrm{~min}$ the cultures were divided into two equal parts. One was ammonia-shocked by addition of $\mathrm{NH}_{4} \mathrm{Cl}$ to $20 \mathrm{mM}$ final concentration (arrow). Sampling and measurement of GS transferase activity were continued. Filled symbols, ammonia-shocked; open symbols, untreated controls. GS activity at time 0 was set to $100 \%$. One-hundred per cent GSI activity ( $g \ln I I$ mutant culture, $a$ ) corresponds to $840 \mathrm{nmol} \gamma$-GH min ${ }^{-1}$ (mg protein) $)^{-1}, 100 \%$ GSII activity ( $g \ln A$ mutant culture, $b$ ) corresponds to $240 \mathrm{nmol} \gamma-\mathrm{GH} \mathrm{min}{ }^{-1}$ (mg protein) $)^{-1}$. The effect of SVPDE on GS transferase activity in crude extracts of ammoniashocked cells of the $g \ln I I$ mutant $(a, \mathrm{ii})$ and $g \ln A$ mutant $(b$, ii) was measured. Ammonia-shocked cultures were incubated with SVPDE (filled symbols) or without SVPDE (open symbols). SEM of three measurements was not more than $10 \%$.
( $90 \%$ reduction), and no PTT was detected on glutamic acid and glutamine ( $>99 \%$ reduction).

One can postulate that the failure to isolate a $S$. coelicolor $\ln A$ mutant by selection of a $\mathrm{Gln}^{-}$phenotype (Fisher, 1992) was due to the expression of the GSII. The fact that $g \ln R$ mutants of $S$. coelicolor could be isolated by this procedure (Wray et al., 1991) suggests that $g \ln R$ in this strain might control both the $g \ln A$ and $g \ln I I$ genes.

\section{GS activities of wild-type $S$. viridochromogenes and gln mutants in liquid cultures with different nitrogen sources}

GS transferase activity of wild-type $S$. viridochromogenes and $g \ln A$ and $g \ln I I$ mutants $\mathrm{DH} 11$ and $\mathrm{DH} 22$ was measured in crude extracts over a period of $12 \mathrm{~d}$. Cells grown on asparagine, $\left(\mathrm{NH}_{4}\right)_{2} \mathrm{SO}_{4}$ or without added nitrogen source were tested (Fig. 4). The wild-type had the highest total GS activity on all media ( $\mathbf{\Delta})$. The GSII activity of the $g \ln A$ mutant $(\square)$ was lower than the GSI activity present in the glnII mutant strain (O).

The heat-stable GSI activity of the wild-type strain $(\triangle)$ was always dominant over the GSII activity (difference between $\Delta$ and $\Delta$ ) irrespective of the type of the nitrogen source in the medium and the ratio between the two activities remained roughly constant. This indicated that there is no differential regulation of the expression of GSI and GSII in response to different nitrogen sources. This is a marked difference to the situation in the Rhizobiaceae and in Frankia sp. strain Cpl1, where GSI alone is present during growth on $\mathrm{NH}_{4}^{+}$ or $\mathrm{N}_{2}$, and GSII is only expressed under conditions of nitrogen starvation (Edmands et al., 1987).

\section{Determination of the covalent modification of GSI and GSII}

Post-translational regulation of GS by the covalent attachment of adenyl groups to prevent metabolic imbalances during sudden changes in ammonia availability is well known (Ginsburg \& Stadtman, 1973). GSI and GSII activities in crude extracts from ammoniashocked cells of $S$. viridochromogenes $g \ln I I$ and $g \ln A$ mutants were examined (Fig. 5). Within $15 \mathrm{~min}$ after ammonia treatment of the cells GSI activity decreased to $55 \%$ (Fig. $5 a$, i), but could be re-activated by SVPDE (Fig. $5 a$, ii), which is known to cleave the AMP moiety of adenylylated E. coli GS (Stadtman et al., 1970; Magasanik, 1982). It can be concluded from these results that the $S$. viridochromogenes GSI is partially inactivated after ammonia treatment, probably by adenylylation as has been shown for S. cattleya, S. coelicolor A3(2) and $S$. clavuligerus (Streicher \& Tyler, 1981; Fisher \& Wray, 1989; Bascarán et al., 1989), and for the Frankia sp. strain Cpll (Edmands et al., 1987). 
Table 3. Feedback inhibition of GSI and GSII of $S$. viridochromogenes

\begin{tabular}{lccccc}
\hline & \multicolumn{2}{c}{$\begin{array}{c}\text { Percentage inhibition } \\
\text { of GSI* }\end{array}$} & & \multicolumn{2}{c}{$\begin{array}{c}\text { Percentage inhibition } \\
\text { of GSII* }\end{array}$} \\
\cline { 2 - 3 } \cline { 5 - 6 } Test metabolite & $1 \mathrm{mM}$ & $10 \mathrm{mM}$ & & $1 \mathrm{mM}$ & $10 \mathrm{mM}$ \\
\hline Alanine & 28 & 81 & & 9 & 28 \\
Glycine & 10 & 48 & & 3 & 25 \\
Serine & 8 & 37 & & 5 & 23 \\
Histidine & 2 & 5 & & $<1$ & $<1$ \\
Tryptophan & $<1$ & $<1$ & & $<1$ & $<1$ \\
CTP & 17 & $>99$ & & 48 & $>99$ \\
UTP & 12 & $>99$ & & 43 & $>99$ \\
AMP & $<1$ & $<1$ & & $<1$ & $<1$ \\
\hline \hline
\end{tabular}

* GS activity was measured by the $\gamma$-glutamyltransferase assay. Determination of GSI activity was performed with crude extracts of the glnII mutant; GSII activity was determined with crude extracts of the $g \ln A$ mutant. The absolute values of GSI and GSII transferase activity are as stated in Fig. 5. GS activity was determined using the means of three assays, SEM was not more than $5 \%$.

The level of adenylylation found in GSI of $S$. viridochromogenes cells grown continuously with ammonia, glutamate or asparagine as nitrogen sources was only about $10 \%$ (not shown). This was comparable to $S$. cattleya, where the highest level of adenylylation was $16 \%$ (Paress \& Streicher, 1985).

GSII activity in crude extracts of DH11 $\left(g \ln A^{-}\right)$ decreased slowly after addition of ammonia. No reactivation was observed after SVPDE treatment. This result suggested that GSII is not regulated by adenylylation, but it does not exclude the possibility of another type of post-translational regulation as has been suggested for Rhizobium leguminosarum GSII (Manco et al., 1992).

\section{Feedback inhibition of GSI and GSII}

Several metabolites were tested for their ability to inhibit $S$. viridochromogenes GSI and GSII in crude extracts (Table 3). 10 mM-concentrations of CTP and UTP, but not AMP, inhibited the transferase activities of GSI and GSII very strongly. Alanine, glycine and serine, but not histidine and tryptophan, also at $10 \mathrm{~mm}$ concentration gave $23-80 \%$ inhibition. With all inhibitors, the GSI activity was more severely reduced than the GSII activity, reflecting the lower $\mathrm{pK}_{\mathrm{i}}$ values of GSII in comparison to GSI (data not shown).

These inhibitory patterns are similar to those observed with other GS enzymes (Hubbard \& Stadtman, 1967; Bhandari et al., 1983; Tsai \& Benson, 1989). Feedback inhibition is of great importance, particularly for organisms with low or no post-translational modification as is the case for some Bacillus species (Hubbard \& Stadtman, 1967; Ojha \& Kantengwa, 1989).

\section{Conclusions}

The coding region $(g \ln A)$ from $S$. viridochromogenes has been amplified by the PCR method, cloned and sequenced. Both the $g \ln A$ and the $g \ln I I$ mutants were glutamine prototrophs, could sporulate and produce PTT. GSI and GSII were expressed under all conditions tested, the GSI activity was always dominant. No differential expression of the two GS in response to the nitrogen source or differentiation was observed. It will be interesting to find out whether the expression of two GS is common in streptomycetes.

This work was supported by BMFT grant 0319374A and grant 20940.78 of the University of Bielefeld. D. Hillemann acknowledged the receipt of a scholarship from the Studiensiftung des deutschen Volkes. We thank T. Kieser for helpful comments on the manuscript, K. H. Hahn, B. Nussbaumer and R. Köplin for helpful discussions, and $\mathrm{I}$. Broer for critical reading of the manuscript.

\section{References}

Adams, T. H. \& Chelm, B. K. (1988). Effects of oxygen levels on the transcription of nif and gln genes in Bradyrhizobium japonicum. Journal of General Microbiology 134, 611-618.

Alijah, R., Dorendorf, J., Talay, S., PüHler, A. \& Wohlleben, W. (1991). Genetic analysis of the phosphinothricin-tripeptide biosynthetic pathway of Streptomyces virdochromogenes Tü494. Applied Microbiology and Biotechnology 34, 749-755.

Almassy, R. J., Janson, C. A., Hamlin, R., Xuong, N.-H. \& EISENBERG, D. (1986). Novel subunit-subunit interactions in the structure of glutamine synthetase. Nature, London 323, 304-309.

ARnOLD, W. \& PÜHLER, A. (1988). A family of high-copy-number plasmid vectors with single end-label sites for rapid nucleotide sequencing. Gene 70, 171-179.

Backman, K., Chen, Y. M. \& Magasanik, B. (1981). Physical and genetic characterization of the $g \ln A-g \ln G$ region of the Escherichia coli chromosome. Proceedings of the National Academy of Sciences of the United States of America 78, 3743-3747.

Bascarán, V., Hardisson, C. \& Braña, A. F. (1989). Regulation of nitrogen catabolic enzymes in Streptomyces clavuligerus. Journal of General Microbiology 135, 2465-2474.

Bayer, E., Gugel, K. H., Hägele, K., Hagenmaier, H., Jessipow, S., KöNIG, W. H. \& ZäHNER, H. (1972). Stoffwechselprodukte von Mikroorganismen: Phosphinothricin und Phosphinothricyl-alanylalanin. Helvetica Chimica Acta 55, 224-239.

Beaucage, S. L. \& Caruthers, H. M. (1981). Desoxynucleoside phosphoramidites: a new class of key intermediates for desoxypolynucleotide synthesis. Tetrahedron Letters 22, 1859-1862.

Behrmann, I., Hillemann, D., Pühler, A., Strauch, E. \& WoHlleben, W. (1990). Overexpression of a Streptomyctes viridochromogenes gene $(g \ln I)$ encoding a glutamine synthetase similar to those of eucaryotes confers resistance against the antibiotic phosphinothricyl-alanyl-alanine. Journal of Bacteriology 172, 5326-5334.

Bender, R. A., Janssen, K. A., Resnick, A. D., Blumenberg, M., FoOR, F. \& MAGASANIK, B. (1977). Biochemical parameters of glutamine synthetase from Klebsiella aerogenes. Journal of Bacteriology 129, 1001-1009.

Bhandari, B., Vairinhos, F. \& Nicholas, D. J. D. (1983). Some properties of glutamine synthetase from Rhizobium japonicum strains CC705 and CC723. Archives of Microbiology 136, 84-88.

Braña, A. F., Paiva, N. \& Demain, A. L. (1986). Pathways and regulation of ammonium assimilation in Stretomyces clavuligerus. Journal of General Microbiology 132, 1305-1317.

de Bruisn, F. J. Rossbach, S., Schneider, M., Ratet, P., Messmer, S., Szeto, W. W., Ausubel, F. M. \& Schell, F. (1989). Rhizobium meliloti 1021 has three differentially regulated loci involved in 
glutamine biosynthesis, none of which is essential for symbiotic nitrogen fixation. Journal of Bacteriology 171, 1673-1682.

Carlson, T. A. \& CHELM, B. K. (1986). Apparent eukaryotic origin of glutamine synthetase II from the bacterium Bradyrhizobium japonicum. Nature, London 322, 568-570.

Cohen, S., Chang, A. C. Y. \& Hsu, L. (1972). Nonchromosomal antibiotic resistance in bacteria : genetic transformation of Escherichia coli by R-Factor DNA. Proceedings of the National Academy of Sciences of the United States of America 69, 2110-2114.

Collasius, M., Falk, H., Ciesler, C. \& Valet, G. (1989). How to build an inexpensive cyclotherm instrument for automated polymerase chain reaction. Analytical Biochemistry 181, 163-166.

Collins, F. S. \& WeISSMAN, S. M. (1984). Directional cloning of DNA fragments at a large distance from an initial probe: a circularization method. Proceedings of the National Academy of Sciences of the United States of America 81, 6812-6816.

Darrow, R. A. \& KNotTs, R. R. (1977). Two forms of glutamine synthetase in free-living root-nodule bacteria. Biochemical and Biophysical Research Communications 78, 554-559.

Darrow, R. A., Crist, D., Evans, W. R., Jones, B. L., Keister, D. L. \& KNOTTS, R. R. (1981). Biochemical and biophysiological studies on the two glutamine synthetases of Rhizobia. In Current Perspectives in Nitrogen Fixation, pp. 182-185. Edited by A. H. Gibson \& W. E. Newton. Canberra: Australian Academy of Science.

DevereuX, J., Haeberli, P. \& Smithies, O. (1984). A comprehensive set of sequence analysis programs for the VAX. Nucleic Acids Research 12, 387-395.

EDMANDS, J., NoRIDGE, N. A. \& Benson, D. R. (1987). The actinorhizal root-nodule symbiont Frankia sp. strain Cpll has two glutamine synthetases. Proceedings of the National Academy of Sciences of the United States of America 84, 6126-6130.

FisHeR, R., TUl, R. \& HASELKORN, R. (1981). A cloned cyanobacterial gene for glutamine synthetase functions in Escherichia coli, but the enzyme is not adenylylated. Proceedings of the National Academy of Sciences of the United States of America 78, 3393-3397.

FISHER, S. H. (1992). Glutamine synthesis in Streptomyces - a review. Gene 115, 13-17.

FISHER, S. H. \& WraY, L. V. (1989). Regulation of glutamine synthetase in Streptomyces coelicolor. Journal of Bacteriology 171 , 2378-2383.

FUCHS, R. L. \& KeISTER, D. L. (1980). Identification of two glutamine synthetases I and II in Rhizobium and Agrobacterium spp. Journal of Bacteriology 141, 996-998.

GinsbuRG, A. \& StadTMAN, E. R. (1973). Regulation of Escherichia coli glutamine synthetase. In The Enzymes of Glutamine Metabolism, pp. 9-43. Edited by S. Prusiner \& E. R. Stadtman. New York: Academic Press.

Gough, J. A. \& MurRay, N. E. (1983). Sequence diversity among related genes for recognition of specific targets in DNA molecules. Journal of Molecular Biology 166, 1-19.

HeINRIKson, R. L. \& KINGDON, H. S. (1971). Primary structure of Escherichia coli glutamine synthetase. II. The complete amino acid sequence of a tryptic heneicosapeptide containing covalently bound adenylic acid. Journal of Biological Chemistry 246, 1099-1106.

HiLl, R. T., PARKER, J. R., GoOdman, H. J. K., Jones, D. T. \& WoOds, D. R. (1989). Molecular analysis of a novel glutamine synthetase of the anaerobe Bacteroides fragilis. Journal of General Microbiology 135, 3271-3279.

Hillemann, D., PüHLeR, A. \& Wohlleben, W. (1991). Gene disruption and gene replacement in Streptomyces via single stranded DNA transformation of integration vectors. Nucleic Acids Research 194, 727-731.

Holmes, D. S. \& QUIGLEY, M. (1981). A rapid boiling method for the preparation of bacterial plasmids. Analytical Biochemistry 114, 193-197.

Hopwood, D. A., Bibb, M. J., Chater, K. F., Kieser, T., Bruton, C. J., KIEser, H. M., Lydiate, D. J., SMith, C. P., WARD, J. M. \& SCHREMPF, H. (1985). Genetic Manipulation of Streptomyces: a Laboratory Manual. Norwich: John Innes Foundation Norwich.

HubBard, J. S. \& StadtMan, E. R. (1967). Regulation of glutamine synthetase. II. Patterns of feedback inhibition in microorganisms. Journal of Bacteriology 93, 1045-1055.
Janssen, P. J., Jones, W. A., Jones, D. T. \& Woods, D. R. (1988) Molecular analysis and regulation of the $\operatorname{gn} A$ gene of the Grampositive anaerobe Clostridium acetobutylicum. Journal of Bacteriology 170, 400-408.

Kumada, Y., Takano, E., Nagaoka, K. \& Thompson, C. J. (1990). Streptomyces hygroscopicus has two glutamine synthetase genes. Journal of Bacteriology 172, 5343-5351.

Kumada, Y., Benson, D. R., HillemanN, D., Hosted, T. J., Rochefort, D. A., Thompson, C. J., Wohlleben, W. \& Tateno, Y. (1993). Evolution of the glutamine synthetase gene, one of the oldest existing and functioning genes. Proceedings of the National Academy of Sciences of the United States of America, 90, 3009-3013.

LuDwiG, R. A. (1978). Control of ammonium assimilation in Rhizobium 32H1. Journal of Bacteriology 135, 114-123.

Ludwig, R. A. (1980a). Physiological roles of glutamine synthetase I and II in ammonium assimilation in Rhizobium sp. 32H1. Journal of Bacteriology 141, 1209-1216.

LuDWIG, R. A. (1980b). Regulation of Rhizobium nitrogen fixation by the unadenylylated glutamine synthetase I system. Proceedings of the National Academy of Sciences of the United States of America 77, $5817-5821$.

MAGASANIK, B. (1982). Genetic control of nitrogen assimilation in bacteria. Annual Review of Genetics 16, 135-168.

Manco, G., Rossi, M., Defez, R., Lamberti, A., Peruoco, G. \& IACCARINo, M. (1992). Dissociation by $\mathrm{NH}_{4} \mathrm{Cl}$ treatment of the enzymic activities of glutamine synthetase II from Rhizobium leguminosarum biovar viceae. Journal of General Microbiology 138, 1453-1460.

Maniatis, T., Fritsch, E. F. \& Sambrook, J. (1982). Molecular Cloning: a Laboratory Manual. Cold Spring Harbor, NY: Cold Spring Harbor Laboratory Press

Martin, G. B., Chapman, K. A. \& Chelm, B. K. (1988). Role of the Bradyrhizobium japonicum ntrC gene product in differential regulation of the glutamine synthetase II gene ( $\ln I I)$. Journal of Bacteriology 170, 5452-5459.

MarTIN, R. (1987). Tools for the molecular biologists: new phage promoter vectors. Focus 9, 11-12.

MERRICK, M. J. (1988). Regulation of nitrogen assimilation by bacteria. In The Nitrogen and Sulphur Cycles, pp. 331-361. Edited by J. A. Cole \& S. J. Ferguson. Cambridge: Cambridge University Press.

Mukhopadhyay, T. \& Roth, J. A. (1991). A simple and efficient method for isolation of DNA fragments from agarose gel. Nucleic Acids Research 19, 6656.

Mullis, K., Faloona, F., Scharf, S., SaIKi, R., Horn, G. \& Erlich, H. (1986). Specific enzymatic amplification of DNA in vitro: the polymerase chain reaction. Cold Spring Harbor Symposia on Quantitative Biology 51, 263-273.

NorRander, J., KeMPE, T. \& Messing, J. (1983). Construction of improved M13 vectors using oligodeoxynucleotide-directed mutagenesis. Gene 26, 101-106.

OCHMAN, H., AJIOKA, J. W., GARZA, D. \& HARTL, D. L. (1990). Inverse polymerase chain reaction. Bio/Technology 8, 759-760.

OJHA, M. \& KANTENGWA, S. (1989). Purification and properties of glutamine synthetase from Bacillus polymyxa. Archives of Microbiology 151, 294-299.

Paress, P. S. \& STREICher, S. L. (1985). Glutamine synthetase of Streptomyces cattleya: purification and regulation of synthesis. Journal of General Microbiology 131, 1903-1910.

Pridmore, R. D. (1987). New and versatile cloning vectors with kanamycin-resistance marker. Gene 56, 309-312.

Rawlings, D. E., Jones, W. A., O'Neill, E. G. \& Woods, D. R. (1987). Nucleotide sequence of the glutamine synthetase gene and its controlling region from the acidophilic autotroph Thiobacillus ferrooxidans. Gene 53, 211-217.

REITZER, L. J. \& MAGASANIK, B. (1987). Ammonia assimilation and the biosynthesis of glutamine, glutamate, aspartate, asparagine, Lalanine, and D-alanine. In Escherichia coli and Salmonella typhimurium, Cellular and Molecular Biology, pp. 302-320. Edited by F. C. Neidhart. Washington, D.C.: American Society for Microbiology.

Rossbach, S., Schell, J. \& DE BruiJn, F. J. (1987). The ntr $C$ gene of 
Agrobacterium tumefaciens C58 controls glutamine synthetase (GSII) activity, growth on nitrate and chromosomal but not Ti-encoded arginine catabolism pathways. Molecular and General Genetics 209, 419-426.

Rossbach, S., Schell, J. \& DE Bruij, F. J. (1988). Cloning and analysis of Agrobacterium tumefaciens C58 loci involved in glutamine biosynthesis: neither the $g \ln A$ (GSI) nor the $g \ln I I$ (GSII) gene plays a special role in virulence. Molecular and General Genetics 212, $38-47$.

Sanger, F., Nicklen, S. \& Coulson, A. R. (1977). DNA sequencing with chain-terminating inhibitors. Proceedings of the National Academy of Sciences of the United States of America 74, 5463-5467.

SHAPIRo, S. \& VINING, L. C. (1983). Nitrogen metabolism and chloramphenicol production in Streptomyces venezuelae. Canadian Journal of Microbiology 29, 1706-1714.

Simon, R., Prirfer, U. \& PÜHLER, A. (1983). A broad host range mobilization system for in vivo genetic engineering: Transposon mutagenesis in Gram-negative bacteria. Bio/Technology 1, 784-791.

Sonnen, H., Kutzner, H. J., BachmanN, F., Thierbach, G., KaUtZ, S., PÜHLER, A. \& SCHÄFER, A. (1991). Neue Plasmide aus Corynebacterium glutamicum und davon abgeleitete Plasmidvektoren. Patent P4027 453.

Stadtman, E. R., Ginsburg, A., Ciardi, J. E., Yeh, J., Hennig, S. B. \& SHAPIRO, B. M. (1970). Multiple molecular forms of glutamine synthetase produced by enzyme catalysed adenylylation and deadenylylation reactions. Advances in Enzyme Regulation 8, 99-118.

Strauch, E., Wohlleben, W. \& Pühler, A. (1987). Development of a plasmid-cloning system for Streptomyces viridochromogenes Tü494. Journal of Basic Microbiology 8, 449-455.
Streicher, S. L. \& TYleR, B. (1981). Regulation of glutamine synthetase activity by adenylylation in the Gram-positive bacterium Streptomyces cattleya. Proceedings of the National Acacdemy of Sciences of the United States of America 78, 229-233.

Tischer, E., DasSarma, S. \& Goodman, H. M. (1986). Nucleotide sequence of an alfalfa glutamine synthetase gene. Molecular and General Genetics 203, 221-229.

Tronick, S. R., Ciardi, J. E. \& Stadtman, E. R. (1973). Comparative biochemical and immunological studies of bacterial glutamine synthetases. Journal of Bacteriology 115, 858-868.

TSAI, Y.-L. \& BENSON, D. R. (1989). Physiological characteristics of glutamine synthetases I and II of Frankia sp. strain Cpll. Archives of Microbiology 152, 382-386.

VieirA, J. \& Messing, J. (1982). The pUC plasmids, an M13mp7derived system for insertion mutagenesis and sequencing with synthetic universal primers. Gene 19, 259-268.

WoHlleben, W. \& PIELsticker, A. (1989). Investigation of plasmid transfer between Escherichia coli und Streptomyces lividans. In DECHEMA Biotechnology Conferences 3, pp. 301-305. Edited by D. Behrens \& A. J. Driesel. Weinheim: VCH Verlagsgesellschaft.

WraY, L. V. \& FisheR, S. H. (1988). Cloning and nucleotide sequence of the Streptomyces coelicolor gene encoding glutamine synthetase. Gene 71, 247-256.

Wray, L. V., AtKinson, M. R. \& Fisher, S. H. (1991). Identification and cloning of the $g \ln R$ locus, which is required for transcription of the glnA gene in Stretomyces coelicolor A3(2). Journal of Bacteriology 173, 7351-7360.

Wright, F. \& BIBb, M. J. (1992). Codon usage in the G+C-rich Streptomyces genome. Gene 113, 55-65. 